\title{
GEOHERITAGE AND TOURISM - OPPORTUNITIES FOR GROWTH
}

\author{
Hrvoje Grofelnik
}

https://doi.org//10.20867/tosee.06.22

\begin{abstract}
Purpose-Contemporary tourism in many developed destinations relies on natural resources, many of which can be directly valorised as tourist attractions. Within natural resources, geoheritage (geological heritage) consists sites or areas of geological features with significant scientific, educational, cultural or aesthetic value. Despite its multiple values, the attractive geosites and their valorisation in tourism are still insufficiently covered.

Methodology - This paper, aims to present the state of the art in a form of a research overview of geoheritage valorisation in tourism by analysing the WoSCC database. The results of overviewing 171 scientific papers on keywords geoheritage and tourism are presented and interpreted in the form of qualitative and quantitative analysis, maps, tabular and graphical representations. To identify the main research links and streams between geoheritage and tourism the bibliometric analysis is carried out using VOSviewer software.

Findings - The papers are classified and it is revealed an insufficient representation of research in the field of tourist valorisation of geoheritage. It is also notable the spatial inhomogeneity towards interest in geoheritage research.

Contribution - The paper brings a research agenda for covering gaps in the further scientific research of the field. The research also points out some possible streams and framework for future geoheritage research that offers new opportunities for the growth of tourism as a responsible and sustainable industry.
\end{abstract}

Keywords: tourism, sustainable tourism, natural heritage, geoheritage, tourist attractions.

\section{INTRODUCTION}

Contemporary tourism in many developed destinations relies on natural resources, many of which are directly valorised as tourist attractions. Within natural resources, this paper singles out geoheritage and analyses the state of the art by overviewing the literature on the topic of geoheritage and tourism in WoSCC database.

The overview of geoheritage research and tourism in this paper is analysing this growing area of scientific interest and points out the agenda for covering gaps in further scientific research.

In recent decades, the scientific and professional public has increasingly followed a trend that can be described by the growth of environmental and geoheritage research, which is evident in the rising number of scientific papers dealing with geotourism (Ólafsdóttir and Tverijonaite 2018). The environmental awareness and interest for the natural heritage of contemporary tourists, who mainly come from developed urban communities, shows a 
ToSEE - Tourism in Southern and Eastern Europe, Vol. 6, pp. 329-342, 2021.

H. Grofelnik: GEOHERITAGE AND TOURISM - OPPORTUNITIES FOR GROWTH

positive trend. Despite the obvious conflict between site protection and economic valorisation, current trends in the development of society indicate a growing awareness of the need to preserve the environment and natural heritage. The most attractive examples of geoheritage are the sites of impressive landscapes, sites of attractive minerals or fossil remains and geolocations with significant contributions to the development of settlements, industry, etc.

Geoheritage is a term that evolved since 1980is as a part of earth sciences and especially geology in the context of natural heritage studies (Cullen 1987). The term has its meaning witch considers: recognising, studying, preserving, education, management and economic valuation of geological heritage. The main institutional frame of preserving and valuing geosites are Geoparks with a network of 169 UNESCO Global Geoparks in 44 countries on five continents (United Nations Educational, Scientific and Cultural Organization 2021). Geoparks are territorial areas with geoheritage of high value to be protected and used for educational, scientific, or tourist purposes and with potential to play an important role in local economy.

The term geotourism has evolved in the context of valuing geoheritage. Hose (1997) defined it in the 1990s and in time, the definition varied. Currently can be described according to Newsome and Dowling (2018), as a form of tourism that focuses on an area's geology and landscape, as the basis of fostering sustainable tourism development to generate benefits for conservation, local communities and the economy (Duarte et al. 2020).

The task of this work is to overview papers that cover the issue of geoheritage aiming to present findings in a form of a framework that impetus the development of the scientific field and valorisation of geoheritage in tourism

To achieve this, the following research questions are defined:

- Research question 1: What is the state of the art in published scientific papers on geoheritage and tourism?

- Research question 2: Where are the gaps in geoheritage research with regard to the possibilities of growth and development of geotourism?

\section{METHODOLOGY}

The study of usage of geoheritage attractions in tourism is a relatively new area of academic research involving multiple disciplines, methodological approaches and topics. Based on this fact as well as on this study's objectives, systematic literature overview is applied. In conducting the overview, a multistep process was used. A comprehensive overview was conducted in January 2021 through searching the Web of Science Core Collection (WoSCC) database for publications that contain the term geoheritage and tourism in the title, abstract or keywords from the early publishing dates to December 2020. WoSCC has international coverage, include top-rated publications and is one of the largest and globally used scientific databases of peer-reviewed literature. 
ToSEE - Tourism in Southern and Eastern Europe, Vol. 6, pp. 329-342, 2021.

H. Grofelnik: GEOHERITAGE AND TOURISM - OPPORTUNITIES FOR GROWTH

A qualitative and quantitative literature overview follows as structured method to address particular research questions and aims for methodological transparency and reliability as well as systematic and comprehensive search on a topic of geoheritage and tourism. The research may also incorporate quasi-statistical approaches in order to categorise, quantify and identify trends in extant research thus assisting in highlighting research gaps and possible streams of future research.

Analysis of the geographic distribution of case studies on geoheritage was made using ArcGIS software, which resulted in editing a map of the world that compares the spatial distribution of conducted case studies of geosites and the number of geoparks per countries.

The analysis of virtual scientific landscape in the research filed of geoheritage was carried out using the VOSviewer software. With VOSviewer software maps was generated to display bibliometric analysis of clusters and their reference networks. Visualisation of bibliometric maps gives an overview of the structure of scientific field visualization of similarities and network association strength by mapping and clustering. In the process of map analysis, it is necessary to notice three basic characteristics; 1 ) distance between terms is smaller and proportional to the number of co-occurrences; 2) diameter and label size indicates the number of occurrences of the corresponding term; 3 ) clusters of related terms are automatically created by software using a weighted and parameterized variant of modularity-based clustering (Van Eck and Waltman et al. 2010).

VOSviewer research was carried out in five steps: (1) the search in WoSCC database for research articles in the period up to the 2020 year using terms geoheritage + tourism in the title, abstract and keywords of the papers; (2) extraction of the data sets from WoSCC compatible for analysis in VOSviewer; (3) a bibliometric analysis in VOSviewer software. To visualise the data and streams properly each data set was analysed with its own number of co-occurrences of a term to obtain clear and legible graphical representations of the relationships in the figures.

\section{RESULTS AND DISCUSSION}

\subsection{Time Analysis of the Research Dynamics}

Analysis of papers with keywords geoheritage and tourism in WoSCC database found that the first paper on the topic is published by Eder in 2008. Since then it is visible positive upward annually trend in the number of published papers (Figure 1).

The search in the period 2008 - 2020 resulted in 190 publications in total. For further analysis are selected articles, proceedings papers and book chapters, which resulted in 171 papers. The analysis revealed 135 articles in the form of a case study of a specific geosite, 14 papers compare different geosites, 16 papers have a theoretical approach on the topic, and 6 papers are written in a form of literature reviews. Analysing publishing dynamics and citation of papers (Figure 1) it can be recognised three waves; first in 2011 and 2012 (evolving period of scientific interest), second-wave 2015 and 2016 (spreading of scientific interest) and recent third-wave and most active period which started in 2018 (acceleration of development of scientific interest). 
ToSEE - Tourism in Southern and Eastern Europe, Vol. 6, pp. 329-342, 2021.

H. Grofelnik: GEOHERITAGE AND TOURISM - OPPORTUNITIES FOR GROWTH

Figure 1: Dynamics of Appearance of Papers with Geoheritage and Tourism Topic

Referred in WoSCC 2008 - 2020

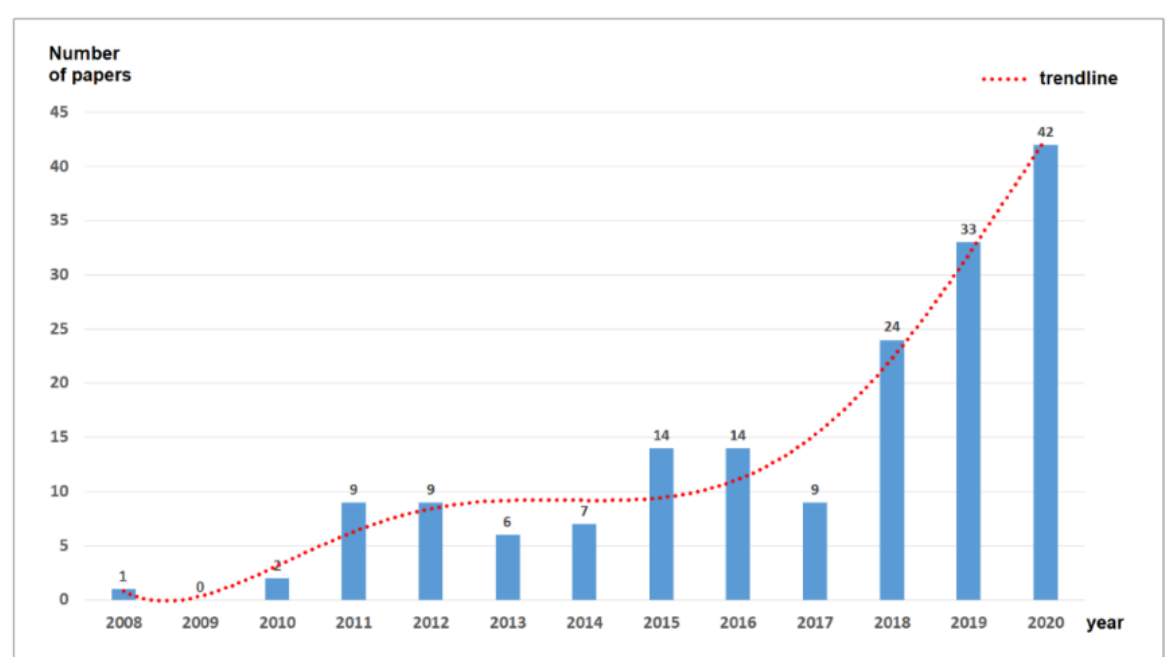

Source: adapted from WoSCC database, 2021

\subsection{Spatial Analysis of the Research Field}

Looking at the spatial interest of researchers on the topic (Table 1 and Figure 2), it is evident that there is no homogeneity at the global level. Several countries such as Russia, Czech Republic, Poland and Serbia are leading in the field. The common feature of these countries is that they are former eastern European countries of similar history, economy and scientific mindset. The rich geodiversity area of Mediterranean countries (such as Italy and Spain) also stands out in the research activity. Although geodiversity and potential exist, a lack of research can be observed from large and developed countries such as the USA, China and India. This suggests that central, eastern and southern European countries have a tradition of research in the analysed field and a broader base of the researchers, while the rest of the countries/universities have individual researches on geoheritage and tourism. 
ToSEE - Tourism in Southern and Eastern Europe, Vol. 6, pp. 329-342, 2021. H. Grofelnik: GEOHERITAGE AND TOURISM - OPPORTUNITIES FOR GROWTH

Table 1: Spatial Distribution of Papers - Top 10 Institutions ( $4 \leq$ research projects)

\begin{tabular}{lrrr}
\hline Institution & $\begin{array}{r}\text { Number of } \\
\text { Papers }\end{array}$ & $\begin{array}{r}\text { Citation } \\
\text { Number of Citation } \\
\text { per Paper }\end{array}$ \\
\hline Czech Academy of Sciences, Brno, Czech Republic & 12 & 63 & 5.25 \\
Southern Federal University, Rostov na Donu, Russia & 11 & 65 & 5.91 \\
Cherepovets State University, Cherepovets, Russia & 10 & 82 & 8.20 \\
University of Wroclaw, Wroclaw, Poland & 9 & 70 & 7.78 \\
University of Novi Sad, Novi Sad, Serbia & 8 & 71 & 8.88 \\
K. G. Razumovsky State University of Technologies & 6 & 4 & 0.67 \\
Management, Moscow, Russia & & & 9.40 \\
Kangwon National University, Chunchon, South & 5 & 47 & 9.00 \\
Korea & & & 6.25 \\
Consiglio Nazionale Delle Ricerche, Sesto Fiorentino, & 4 & 36 & 2.25 \\
Italy & 4 & 25 & 1.00 \\
Mendel University, Brno, Czech Republic & 4 & 9 & 2.25 \\
Mohammed V University Rabat, Rabat, Morocco & 4 & 112 & \\
Murdoch University, Perth, Australia & 4 & 4 & \\
Universidad de la Laguna, San Cristobal la Laguna, & & & \\
Spain & 4 & 9 & \\
University of Molise, Pesche, Italy & & & \\
\hline
\end{tabular}

Source: adapted from WoSCC database, 2021

Figure 2: Location of Geoheritage Case Studies and Number of Geoparks per Countries

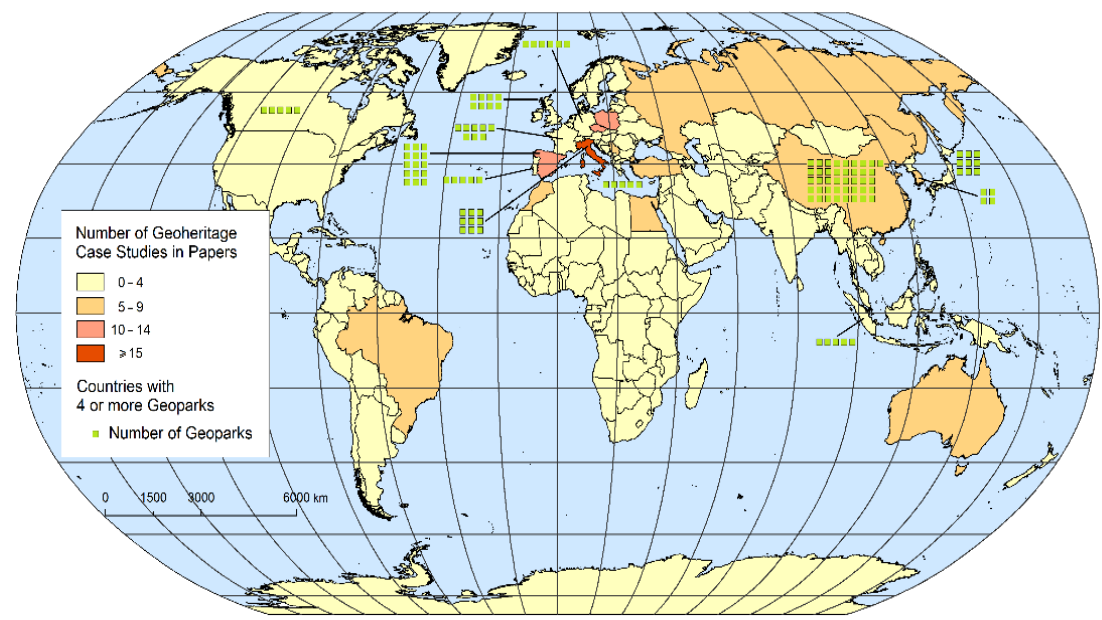

Source: adapted from WoSCC database, 2021

So far, national scientific institutions within a particular state have conducted most geoheritage case study research. As an exception can be mentioned the institutions and authors from the Russian Federation, who are above average active in contributing to the development of the scientific field outside their homeland (Molchanova and Ruban 2019; Habibi et al. 2018; Ruban et al. 2018; Sallam et al. 2018). 
ToSEE - Tourism in Southern and Eastern Europe, Vol. 6, pp. 329-342, 2021.

H. Grofelnik: GEOHERITAGE AND TOURISM - OPPORTUNITIES FOR GROWTH

The analysis of the spatial distribution of papers in the form of case studies and the location of geoparks as recognized areas of scientific, educational, aesthetic and tourist interest shows that not all world is equally researched (Figure 2). It can be noticed that there is a higher concentration of geoparks in Europe, which is related and followed the increased number of published case studies of Geoparks and their recognisability not only in the scientific community but also in the tourism industry. Italy stands out as an example of good practice between the protection of geoheritage, scientific research and tourist interest (Burlando et al. 2011; Pelfini and Bollati 2014; Bollati et al. 2018; Pica et al. 2018; Valente et al. 2020). The lack of Geoparks outside Europe, especially in the economically developed countries, shows that countries have other legal models of protection, and the scientific visibility of geoheritage research interest has yet to follow.

\subsection{Interest of Journal for Papers in the Field of Geoheritage}

The analysis of over two decades shows the domination of the journal Geoheritage. According to the number of published papers and citations, Geoheritage has four times more papers than the first following journal.

The five most active journals out of the total number of papers included in this analysis, give $51 \%$ of papers: Geoheritage - Springer (50 articles, Q2), Geosciences - MDPI (12 articles, Q2), Resources - MDPI (9 articles, Q2), Sustainability - MDPI (8 articles, Q2), Quaestiones Geographicae - Adam Mickiewicz University (7 articles, Q3).

The analysis of the journal's research area shows that geology as science field of journals that published papers dominates with $59.3 \%$, while other journals with interest in other areas of scientific research are smaller: geography $14.0 \%$, environmental sciences $12.8 \%$, science of technologies $11.5 \%$ and $2.4 \%$ from business economics. It is important to point out that the contribution and citations are not in line with this, for example, one of the most cited papers is The nature and management of geotourism: A case study of two established iconic geotourism destinations (Newsome et al. 2012) which comes from the field of business economics and has 85 citations.

\subsection{Qualitative Analysis of Most Cited and Singled out Papers}

A comparative content analysis of the five most cited papers in the WoSCC database on the topics of geoheritage + tourism reveals that the dominant research method is qualitative and the results are mainly descriptive (Table 2). Four of the five most cited papers are published in the journal Geoheritage and only one in Tourism Management Perspectives. All papers are published in 2011 and 2012 that can be connected to the first wave of scientific interest in the geoheritage field (Figure 1). The first wave is dominated by a theoretical approach to geoheritage and attempts to link the topic to compatible areas of valuation such as cultural heritage. 
ToSEE - Tourism in Southern and Eastern Europe, Vol. 6, pp. 329-342, 2021.

H. Grofelnik: GEOHERITAGE AND TOURISM - OPPORTUNITIES FOR GROWTH

Table 2: Comparative Content Analysis of the Five Most Cited Papers in the WoSCC Database on the Topics of Geoheritage and Tourism

\begin{tabular}{|c|c|c|c|c|c|}
\hline Title & Authors & Journal (year) & Cited & $\begin{array}{l}\text { Research } \\
\text { Method / } \\
\text { Technique }\end{array}$ & Results \\
\hline $\begin{array}{l}\text { Geotourism's } \\
\text { Global Growth }\end{array}$ & Dowling, R.K. & $\begin{array}{l}\text { Geoheritage } \\
\text { (2011) }\end{array}$ & 180 & $\begin{array}{l}\text { Qualitative } \\
\text { observation } \\
\text { / } \\
\text { Content } \\
\text { analysis }\end{array}$ & $\begin{array}{l}\text { Describes } \\
\text { geotourism as a form } \\
\text { of tourism that } \\
\text { creates new } \\
\text { experiences and } \\
\text { promotes the } \\
\text { protection of } \\
\text { geological heritage } \\
\text { for the benefit of the } \\
\text { local community. }\end{array}$ \\
\hline $\begin{array}{l}\text { Rediscovering a } \\
\text { Sense of Wonder: } \\
\text { Geoheritage, } \\
\text { Geotourism and } \\
\text { Cultural } \\
\text { Landscape } \\
\text { Experiences }\end{array}$ & Gordon, J.E. & $\begin{array}{l}\text { Geoheritage } \\
(2012)\end{array}$ & 89 & $\begin{array}{l}\text { Qualitative } \\
\text { observation } \\
\text { / } \\
\text { Comparative } \\
\text { analysis }\end{array}$ & $\begin{array}{l}\text { Connects the } \\
\text { influence of nature } \\
\text { (geodiversity and } \\
\text { landscape) on people } \\
\text { in the context of } \\
\text { literature and art } \\
\text { aiming at } \\
\text { geoconservation. }\end{array}$ \\
\hline $\begin{array}{l}\text { The nature and } \\
\text { management of } \\
\text { geotourism: A } \\
\text { case study of two } \\
\text { established iconic } \\
\text { geotourism } \\
\text { destinations }\end{array}$ & $\begin{array}{l}\text { Newsome, D., } \\
\text { Dowling, R., } \\
\text { \& Leung, Y.F. }\end{array}$ & $\begin{array}{l}\text { Tourism } \\
\text { Management } \\
\text { Perspectives } \\
\text { (2012) }\end{array}$ & 85 & $\begin{array}{l}\text { Qualitative } \\
\text { observation } \\
\text { / } \\
\text { Comparative } \\
\text { analysis }\end{array}$ & $\begin{array}{l}\text { Describes the } \\
\text { management } \\
\text { perspective on the } \\
\text { impact of } \\
\text { degradation } \\
\text { problems on } \\
\text { geotourism sites. }\end{array}$ \\
\hline $\begin{array}{l}\text { Quantitative } \\
\text { Assessment of } \\
\text { Geotopes as an } \\
\text { Effective Tool for } \\
\text { Geoheritage } \\
\text { Management }\end{array}$ & $\begin{array}{l}\text { Fassoulas, C., } \\
\text { Mouriki, D., } \\
\text { Dimitriou- } \\
\text { Nikolakis, P., } \\
\& \\
\text { Iliopoulos, G. }\end{array}$ & $\begin{array}{l}\text { Geoheritage } \\
(2012)\end{array}$ & 69 & $\begin{array}{l}\text { Quantitative } \\
\text { observation } \\
\text { / } \\
\text { Content } \\
\text { analysis }\end{array}$ & $\begin{array}{l}\text { Show's development } \\
\text { of quantitative } \\
\text { evaluation } \\
\text { methodology for the } \\
\text { sustainable } \\
\text { management } \\
\text { and conservation of } \\
\text { geotopes. }\end{array}$ \\
\hline $\begin{array}{l}\text { Geotourism in } \\
\text { Volcanic and } \\
\text { Geothermal } \\
\text { Environments: } \\
\text { Playing with Fire? }\end{array}$ & $\begin{array}{l}\text { Erfurt- } \\
\text { Cooper, P. }\end{array}$ & $\begin{array}{l}\text { Geoheritage } \\
\text { (2011) }\end{array}$ & 47 & $\begin{array}{l}\text { Qualitative } \\
\text { observation } \\
\text { / } \\
\text { Comparative } \\
\text { analysis }\end{array}$ & $\begin{array}{l}\text { Presents a review of } \\
\text { the tourism literature } \\
\text { on volcano risk } \\
\text { management and } \\
\text { geothermal tourism } \\
\text { with a review of the } \\
\text { necessary knowledge } \\
\text { on potential volcanic } \\
\text { hazards. }\end{array}$ \\
\hline
\end{tabular}

Source: adapted from WoSCC database, 2021

An overview of all 171 selected articles in the WoSCC database revealed the dominance of papers with a descriptive approach in describing a particular geosite. This is the result of the relative novelty of the researched area, but also the professional orientation of the authors themselves, among whom dominate geologists. Since this review paper, aims to give an overview of the topic from the aspect of tourist valorisation of geoheritage among the selected papers four groups of paper topics will be analysed more in detail. 
ToSEE - Tourism in Southern and Eastern Europe, Vol. 6, pp. 329-342, 2021.

H. Grofelnik: GEOHERITAGE AND TOURISM - OPPORTUNITIES FOR GROWTH

\subsubsection{Valorisation of Geoheritage in Urban Areas (in-situ and ex-situ)}

In the WoSCC database, eight papers were found, among which stand out Habibi et al. (2018), which argues three values of geoheritage: scientific, educational and touristic. This division is important because it points out the potential of interest groups and ways of presenting and shaping the tourist offer in the process of evaluating geoheritage. Furthermore, the paper Pica et al. (2018) stands out, which provides links between cultural and geological heritage and it is has innovative upgrading geotourism itineraries with the usage of digital geotourism tools. Significant papers are also Kubalíková and Bajer (2018) and Kubalíková et al. (2017) which emphasize the value of merging elements of cultural heritage and geoheritage on the example of ex-situ geodiversity like museums and building stones materials. The papers also describe anthropogenic landforms in a way of secondary geodiversity forms like old quarries and underground spaces.

\subsubsection{The use of ICT in the Valorisation of Geoheritage}

Six papers describe the use of digital and geomatic tools to bring geotourism close to a wide audience combining geological with other tourist attractions (Filocamo et al. 2020). ICT technologies can help overcome language barriers and with interactivity can attract a wider audience. The APPs offer real-time interaction, possibilities of augmented reality with different thematic layers and can be used in didactic, scientific and tourism functions. Multimedia approach in presenting geoheritage offers combining thematic layers, photographs, diagrams, description cards, 3D virtual flights etc. (Martínez-Graña et al. 2018 and 2019) so the audience is more easily attracted to geoheritage. It is of special importance to notice the possibilities of smartphones APPs in urban geotourism (Pica et al. 2018; Reynard et al. 2015) which are offering links between geodiversity, architecture and culture in an urban environment.

2.4.3. Combining the Offer of Outdoor Sports and Recreation Activities with Geoheritage and Geotourism

Linking geoheritage knowledge with sports, recreation activities and outdoor experience offers added value in all three aspects. Because of its habitus and interest, the sports competitors have willing for participating in geoparks outdoor events. Geotourism services are offering the possibility of adding value to the specific outdoor activities (Bollati et al. 2018) like hiking, climbing, canyoning, speleology, trail events and many others. With the positive trend of linking recreation and sports activities, especially with the rising consciousness of the public in health issues, which are also a consequence of the COVID19 pandemic, the outdoor spaces with geoheritage are begun to be closer to the potential tourist's audience (Justice 2018).

\subsubsection{Combining the Offers of Medical Tourism with the Valuation of Geoheritage}

Only two papers recognized the potential of geoheritage as a tourist resource for the development of medical treatment and complementary services (Fedorov and Ruban 2019; Fedorov et al. 2019) Both papers discuss the sustainable management of natural resources in balneology, first the use of coastal muds and second the use of salt lakes mud for medical therapeutic purposes. 
ToSEE - Tourism in Southern and Eastern Europe, Vol. 6, pp. 329-342, 2021. H. Grofelnik: GEOHERITAGE AND TOURISM - OPPORTUNITIES FOR GROWTH

\section{BIBLIOMETRIC ANALYSIS}

The data set consisted of paper 4531 co-citations and in the process of analysing data with VOSviewer software minimum limit of co-citation was set on 30 citations, which resulted in a list of 22 journals visualised as a network in Figure 3.

\section{Figure 3: Paper Co-citation Report by Source of Most Cited Journals}

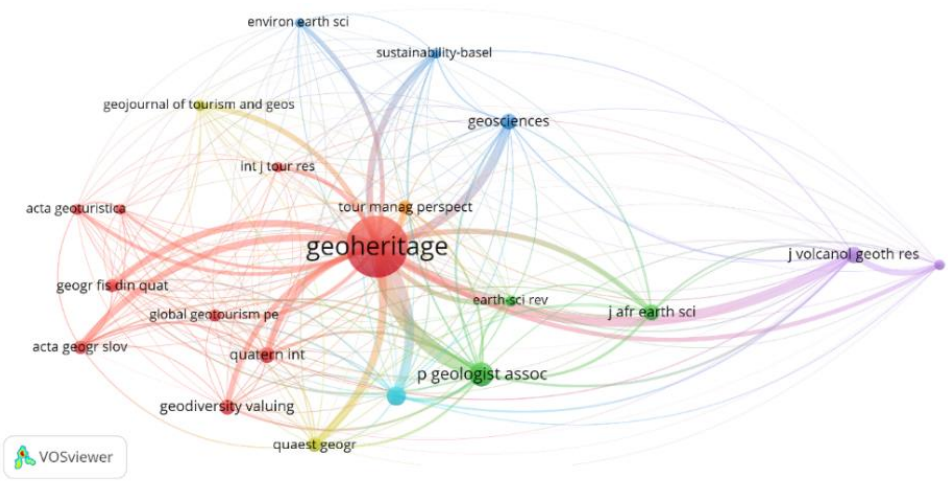

Source: adapted from WoSCC database, 2021; VOSviewer, 2021

The journal that dominates in this analysis is Geoheritage, with 936 co-citations. This is the result of the specialisation of the journal in the scientific field. To emphasis the gap between all other journals and journal Geoheritage it can be mentioned that the second journal in this rank has more than five times smaller co-citation.

Figure 4: Co-citation Report by Most Cited Authors

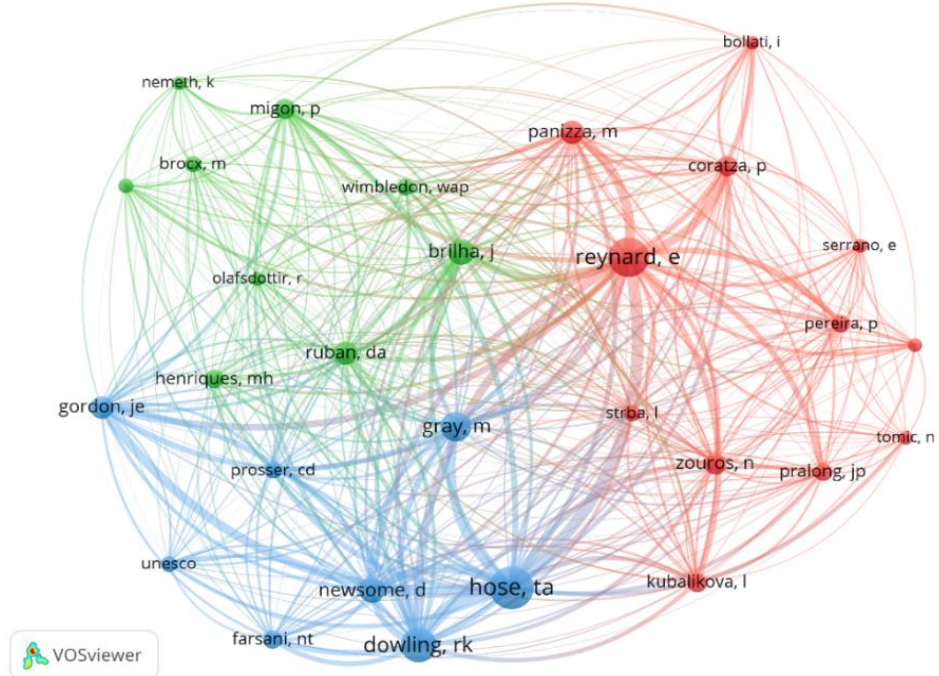

Source: adapted from WoSCC database, 2021; VOSviewer, 2021 
ToSEE - Tourism in Southern and Eastern Europe, Vol. 6, pp. 329-342, 2021.

H. Grofelnik: GEOHERITAGE AND TOURISM - OPPORTUNITIES FOR GROWTH

The data set consisted 5526 authors' co-citations and in the process of analysing data with VOSviewer software, minimum limit of co-citation was set on 30 citations, resulted in a list of 29 authors visualised as a network in Figure 4. Analysis of the author's co-citation in VOSviewer with the most occurrences showed that the most cited authors indexed in the WoSCC database are Dowling R.K. with 184 citations, Hose T.A. with 84 and Reynard E. with 22 citations. In further analysis are considered the three most cited papers of the most influenced authors in VOSviewer analysis of co-citations.

Paper Geotourism's Global Growth with 180 citations is one of the first articles on the topics of valuing geoheritage in tourism and certainly the theoretical paper with major influence on the development of the field. In this work, Dowling (2011) defined geotourism, its elements, activities and connections with geoparks. Paper The English Origins of Geotourism (As a Vehicle for Geoconservation) And Their Relevance to Current Studies (Hose, 2011), with 37 citations is a paper that argues the multidisciplinary nature of geotourism research and notes the evolving geotourism research and interaction between geotourism and geoparks. Paper GeoGuides, Urban Geotourism Offer Powered by Mobile Application Technology (Pica et al. 2018), with 22 citations argues urban tourism offer based on natural aspects of urban areas and the use of digital geotourism tools like apps for smartphones.

\section{Figure 5: Co-occurance of Most Used Keywords in Papers}

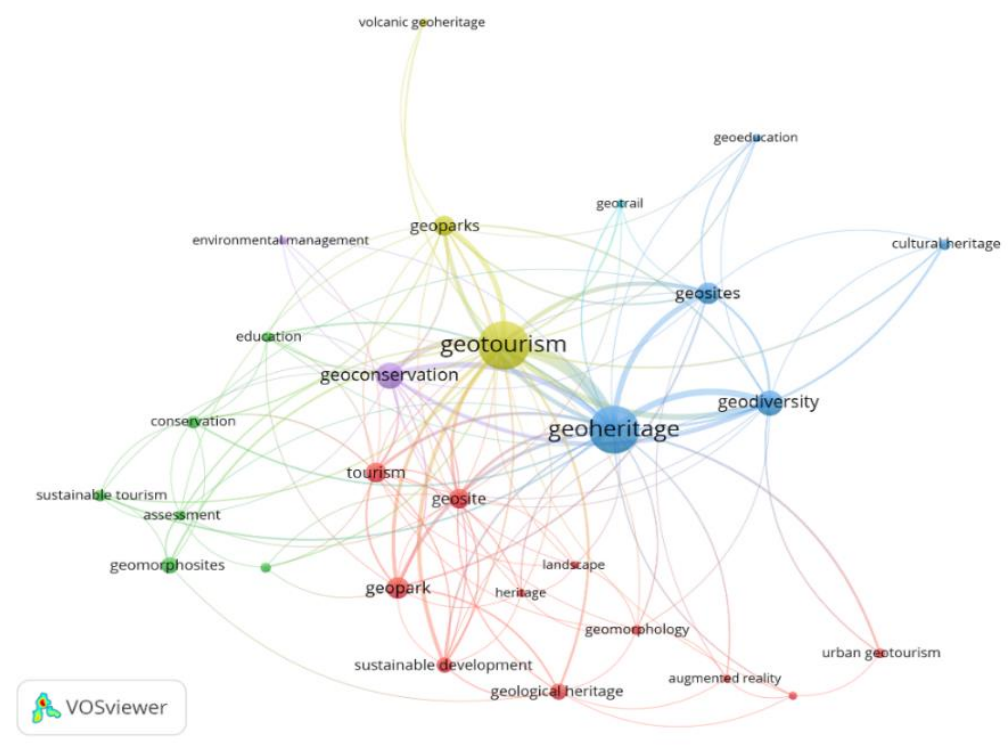

Source: adapted from WoSCC database, 2021; VOSviewer, 2021

In the data set was found 560 keywords and in the process of analysing data with VOSviewer software, with the minimum limit of three co-occurance keywords in papers, the result was 28 words visualised as a network in Figure 5. The primary group of terms, according to the strength of the connections, consists of terms geoheritage, geotourism and tourism, which are standing out to other terms, which confirm the value of geoheritage in 
ToSEE - Tourism in Southern and Eastern Europe, Vol. 6, pp. 329-342, 2021.

H. Grofelnik: GEOHERITAGE AND TOURISM - OPPORTUNITIES FOR GROWTH

shaping the tourist offer. In the semantic analysis, there is a need for merging of occurrence of the terms geoparks and geopark, which are secondary according to mutual connections and indicates the importance of recognizing and management of geoheritage for tourism purposes. The tertiary group of terms are education and conservation, which are indicating the need for sustainable development and contribution of geoheritage valorisation to the community.

\section{CONCLUSION}

After overviewing published papers in the WoSCC database in the context of development phases of the scientific field it can be concluded that, it is necessary to enter the next development phase. In the part of the conclusion that follows are singled out points of the scientific field in which can be made a step forward.

The overall analysis shows a lack of papers in the field of management of tourism valuation of geoheritage, which is a mostly consequence of the neglect of geoheritage as a tourist attractions. So far, geoheritage research has been mostly related to experts in the field of geology and geomorphology, and the possibility of future development is obvious through an interdisciplinary approach and the involvement of experts in the field of tourism management. It is especially necessary to emphasize the possibilities for international cooperation both in the scientific field and in the proclamation of institutional protected areas like geoparks. International cooperation in the form of institutional cooperation and the transfer of experience and knowledge outside the home countries is needed as a step forward in the next development phase. Given that geological heritage knows no national borders and often extends beyond borders, more attention needs to be paid to cross-border international projects in the future phase of research. Geologically attractive areas are often mountainous areas that are often physical and national borders between countries, which often caused its marginalisation in the past. Given the policies of interstate integration and cross-border cooperation with the leading example of the European Union and financial resources intended for crossborder cooperation, it is necessary to recognize this opportunity for growth. Development of the geotourism and valorisation of once marginal and neglected crossborder areas can today be a link for new cooperation in science, tourism and contribute to local economic development.

Unlike the research until now, which have been strongly case-oriented and mostly focused on the geoparks, in the future it is not necessary to wait for institutional recognition of geosties for their valuation in geotourism. Also, the appearance of papers that correspond to the issue of geoheritage in urban areas is interesting for the future growth of geotourism. Papers that are arguing urban geoheritage recognize many ex situ geosites like museums, monuments, info panels and similar installations that can offer new tourism experiences and add value to urban destinations. In the trend of new changes in tourism within the implementation of $5 \mathrm{G}$ technologies and the development of smart cities, it is also important to see opportunities for growth and development of new geotourism services based on real-time geopositioning, augmented reality and developing other network services. 
ToSEE - Tourism in Southern and Eastern Europe, Vol. 6, pp. 329-342, 2021.

H. Grofelnik: GEOHERITAGE AND TOURISM - OPPORTUNITIES FOR GROWTH

Figure 6. Graphical Conclusion - Framework for Geoheritage and Tourism Growth

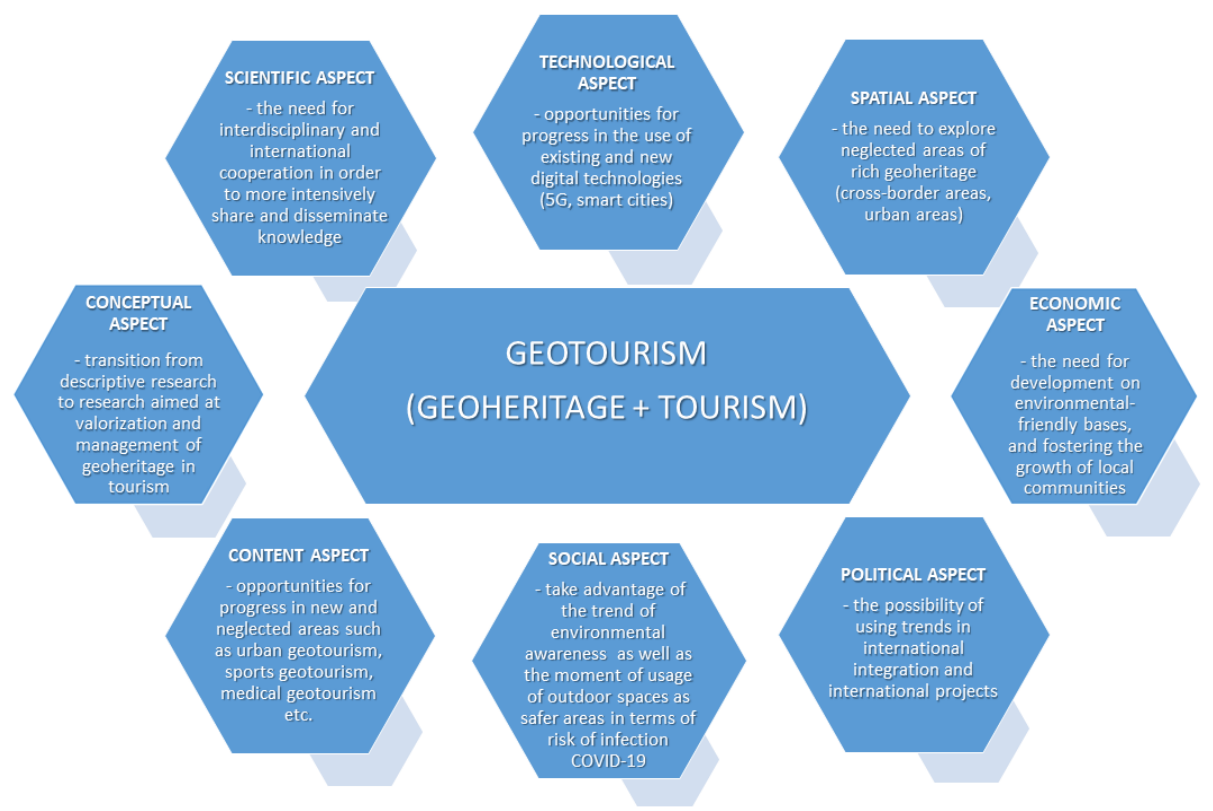

Implementation of the framework (like Figure 6) can generate growth, both for science and geotourism, but also carries the challenge of conflicts between environmental preservation and intensification of pressure on geosites. Therefore, geotourism in the future should be based on scientific research and management of geoheritage with a focus on geoconservation and geoeducation, which will create a strong relationship with sustainable tourism development and economic benefits for local communities.

\section{Limitations of this research}

Regarding the limitations of this study, only the WoSCC database has been searched witch is well regarded among the research authors for peer-review rigour and guarantees that the author of this study is assessing papers that are reaching the widest possible audience. It is also possible that there were papers dealing with tourism and geological heritage in the WoSCC database, but they did not use the terms geoheritage and tourism in the title, abstract and keywords.

\section{REFERENCES}

Bollati, I., Coratza, P., Panizza, V. and PelfIni, M. (2018), „Lithological and structural control on Italian mountain geoheritage: opportunities for tourism, outdoor and educational activities“, Quaestiones Geographicae, Vol. 37, No. 3, pp. 53-73, https://doi 10.2478/quageo-2018-0025

Burlando, M., Firpo, M., Queirolo, C., Rovere, A. and Vacchi, M. (2011), „From geoheritage to sustainable development: strategies and perspectives in the Beigua Geopark (Italy)“, Geoheritage, Vol. 3, No. 2, pp. 63-72, https://doi 10.1007/s12371-010-0019-4 
ToSEE - Tourism in Southern and Eastern Europe, Vol. 6, pp. 329-342, 2021. H. Grofelnik: GEOHERITAGE AND TOURISM - OPPORTUNITIES FOR GROWTH

Cullen, P. (1987), "Managing the Coastal Heritage of Australia in Coastal Zone '87”, in Magoon, O.T. (Ed.), Fifth Symposium on Coastal and Ocean Management, American Society of Civil Engineers, New York

Dowling, R.K. (2011), Geotourism's global growth. Geoheritage, Vol. 3, No. 1, pp. 1-13, https://doi $10.1007 / \mathrm{s} 12371-010-0024-7$

Dowling, R. and Newsome, D. (2018), Handbook of geotourism. Edward Elgar Publishing, Murdoch University, Australia

Duarte, A., Braga, V., Marques, C. and Sá, A.A. (2020), "Geotourism and Territorial Development: A Systematic Literature Review and Research Agenda", Geoheritage, Vol. 12, No. 3, pp. 1-19, https://doi.org/10.1007/s12371-020-00478-Z

Eder, W. (2008), "Geoparks-promotion of earth sciences through geoheritage conservation, education and tourism", Journal of the Geological Society of India, Vol. 72, No. 2, pp. 149-154

Erfurt-Cooper, P. (2011), "Geotourism in volcanic and geothermal environments: playing with fire?", Geoheritage, Vol. 3, No. 3, pp. 187-193, https://doi 10.1007/s12371-010-0025-6

Fassoulas, C., Mouriki, D., Dimitriou-Nikolakis, P. and Iliopoulos, G. (2012), "Quantitative assessment of geotopes as an effective tool for geoheritage management", Geoheritage, Vol. 4, No. 3, pp. 177 193, https://doi 10.1007/s12371-011-0046-9

Fedorov, Y.A. and Ruban, D.A. (2019), "The source of the geoheritage of small sludge lakes in the semi-arid environments of the Russian south", Resources, Vol. 8, No. 2, pp. 75, https://doi.org/10.3390/resources8020075

Fedorov, Y.A., Gar'kusha, D.N., Trubnik, R.G., Latushko, N.A. and Ruban, D.A. (2019), “Coastal peloids as geological heritage: evidence from the Taman Peninsula (southwestern Russia)", Water, Vol. 11, No. 6, pp. 1119, https://doi.org/10.3390/w11061119

Filocamo, F., Di Paola, G., Mastrobuono, L. and Rosskopf, C.M. (2020), "MoGeo, a Mobile Application to Promote Geotourism in Molise Region (Southern Italy)", Resources, Vol. 9, No. 3, pp. 31, https://doi.org/10.3390/resources9030031

Gordon, J.E. (2012), "Rediscovering a sense of wonder: geoheritage, geotourism and cultural landscape experiences", Geoheritage, Vol. 4, No. 1-2, pp. 65-77, https://doi 10.1007/s12371-011-0051-z

Habibi, T., Ponedelnik, A.A., Yashalova, N.N. and Ruban, D.A. (2018), "Urban geoheritage complexity: Evidence of a unique natural resource from Shiraz city in Iran", Resources Policy, Vol. 59, pp. 8594, https://doi.org/10.1016/j.resourpol.2018.06.002

Hose, T.A. (1997), „Geotourism - selling the Earth to Europe“, in: Marinos, P.G., Koukis, G.C., Tsiambaos, G.C., Stournaras, G.C., Engineering Geology and the Environment, A.A. Balkema, Rotterdam, pp. 2955-2960.

Hose, T.A. (2011), „The English origins of geotourism (as a vehicle for geoconservation) and their relevance to current studies“, Acta Geographica Slovenica, Vol. 51, No. 2, pp. 343-359, https://doi.org/10.3986/AGS51302

Justice, S.C. (2018), "UNESCO global geoparks, geotourism and communication of the earth sciences: A case study in the Chablais UNESCO Global Geopark, France”. Geosciences, Vol. 8, No. 5, pp. 149, https://doi.org/10.3390/geosciences8050149

Kubalíková, L. and Bajer, A. (2018), „Geotourism within urban areas: new ways of promotion of natural and cultural heritage (case study from Brno city)“, in Svobodova, H. (Ed.), 25th Central European Conference on Useful Geography: Transfer from Research to Practice, Masaryk University, Brno, pp. 462-472., https://doi.org/10.5817/CZ.MUNI.P210-8908-2018

Kubalíková, L., Kirchner, K. and Bajer, A. (2017), "Secondary geodiversity and its potential for urban geotourism: a case study from Brno city, Czech Republic", Quaestiones Geographicae, Vol. 36, No. 3, pp. 63-73, https://doi.org/10.1515/quageo-2017-0024

Martínez-Graña, A., González-Delgado, J.Á., Ramos, C. and Gonzalo, J.C. (2018), "Augmented Reality and Valorizing the Mesozoic Geological Heritage (Burgos, Spain)”, Sustainability, Vol. 10, No. 12, pp. 4616, https://doi.org/10.3390/su10124616

Martínez-Graña, A.M., Goy, J.L., González-Delgado, J.Á., Cruz, R., Sanz, J., Cimarra, C. and De Bustamante, I. (2019), "3D virtual itinerary in the geological heritage from natural areas in Salamanca-ÁvilaCáceres, Spain”, Sustainability, Vol. 11, No. 1, pp. 144, https://doi.org/10.3390/su11010144

Molchanova, T.K. and Ruban, D.A. (2019), „New evidence of the Bangestan geoheritage resource in Iran: beyond hydrocarbon reserves“, Resources, Vol. 8, No. 1, pp. 35, https://doi.org/10.3390/resources8010035

Newsome, D., Dowling, R. and Leung, Y.F. (2012), "The nature and management of geotourism: A case study of two established iconic geotourism destinations", Tourism management perspectives, Vol. 2, pp 19-27, https://doi.org/10.1016/j.tmp.2011.12.009 
ToSEE - Tourism in Southern and Eastern Europe, Vol. 6, pp. 329-342, 2021. H. Grofelnik: GEOHERITAGE AND TOURISM - OPPORTUNITIES FOR GROWTH

Newsome, D. and Dowling, R. (2018), „Geoheritage and geotourism. Geoheritage - Assessment, Protection, and Management“, Geoheritage, Elsevier, pp. 305 - 321, https://doi.org/10.1016/B978-0-12809531-7.00017-4

Ólafsdóttir, R. and Tverijonaite, E. (2018), "Geotourism: a systematic literature review”, Geosciences, Vol. 8, No. 7, pp. 234, https://doi.org/10.3390/geosciences 8070234

Pelfini, M. and Bollati, I. (2014), „Landforms and geomorphosites ongoing changes: Concepts and implications for geoheritage promotion“, Quaestiones Geographicae, Vol. 33, No. 1, pp. 131-143., https://doi 10.2478/quageo-2014-0009,

Pica, A., Reynard, E., Grangier, L., Kaiser, C., Ghiraldi, L., Perotti, L. and Del Monte, M. (2018), “GeoGuides, urban geotourism offer powered by mobile application technology”, Geoheritage, Vol. 10, No. 2, pp. 311-326, https://doi.org/10.1007/s12371-017-0237-0

Reynard, E., Kaiser, C., Martin, S. and Regolini, G. (2015), “An application for Geosciences communication by smartphones and tablets", in Engineering Geology for Society and Territory, Vol. 8, pp. 265 268, Springer, https://doi.org/10.1007/978-3-319-09408-3_46

Ruban, D.A., Tiess, G., Sallam, E.S., Ponedelnik, A.A. and Yashalova, N.N. (2018), „Combined mineral and geoheritage resources related to kaolin, phosphate, and cement production in Egypt: Conceptualization, assessment, and policy implications“, Sustainable Environment Research, Vol. 28, No. 6, pp. 454-461, https://doi.org/10.1016/j.serj.2018.08.002

Sallam, E.S., Ponedelnik, A.A., Tiess, G., Yashalova, N.N. and Ruban, D.A. (2018), „The geological heritage of the Kurkur-Dungul area in southern Egypt“, Journal of African Earth Sciences, Vol. 137, pp. 103-115, https://doi.org/10.1016/j.jafrearsci.2017.10.012

Valente, E., Santo, A., Guida, D. and Santangelo, N. (2020), „Geotourism in the Cilento, Vallo di Diano and Alburni UNESCO Global Geopark (Southern Italy): The Middle Bussento Karst System“, Resources, Vol. 9, No. 5, pp. 52, https://doi.org/10.3390/resources9050052

Van Eck, N.J. and Waltman, L. (2010), "Software survey: VOSviewer, a computer program for bibliometric mapping”, Scientometrics, Vol. 84, No. 2, pp. 523-538, https://doi 10.1007/s11192-009-0146-3

United Nations Educational, Scientific and Cultural Organization - List of UNESCO Global Geoparks (UGGp), viewed $04^{\text {th }}$ April 2021, http://www.unesco.org/new/en/natural-sciences/environment/earthsciences/unesco-global-geoparks/list-of-unesco-global-geoparks/

Hrvoje Grofelnik, $\mathrm{PhD}$, Assistant Professor

University of Rijeka, Faculty of Tourism and Hospitality Management

Department of Multidisciplinary Areas

Primorska 46, Opatija, Croatia

$+385-51-294691$

hrvoje.grofelnik@fthm.hr 